\title{
Lidia Wiatrak
}

Uniwersytet Ekonomiczny we Wrocławiu

e-mail: lidia.wiatrak@ue.wroc.pl

\section{REFORMA APARATU SKARBOWEGO - UTWORZENIE KRAJOWEJ ADMINISTRACJI SKARBOWEJ}

\section{TAX SYSTEM REFORM - CREATION OF THE NATIONAL REVENUE ADMINISTRATION}

DOI: $10.15611 / \mathrm{pn} .2019 .544 .23$

JEL Classification: H25, K34

Streszczenie: Przedmiotem artykułu jest ocena reformy aparatu skarbowego wprowadzonej ustawą z dnia 16 listopada 2016 r. o Krajowej Administracji Skarbowej (KAS). Oceny dokonano w odniesieniu do zasadniczych problemów, które dotykały funkcjonującej do marca 2017 r. administracji podatkowej i celnej. W niniejszym opracowaniu podjęto próbę odpowiedzi na pytanie: Jakie argumenty przemawiały za koniecznością reformy finansów publicznych w zakresie przebudowy aparatu skarbowego? Zaprezentowane aspekty integracji administracji celnej i podatkowej w ramach jednej instytucji, a także korzyści, jakie niesie reforma dotychczasowych struktur, w pełni uzasadniają odpowiedź na sformułowane pytanie. W artykule skoncentrowano się na teoretycznych rozważaniach, których podstawowym celem jest uzasadnienie konieczności utworzenia KAS w kontekście zdiagnozowanych problemów funkcjonowania administracji skarbowej w Polsce. Do prezentacji omawianych zagadnień wykorzystano metodę analizy aktów prawnych, statystyk publikowanych przez administrację skarbową, informacji prasowych oraz publikacji naukowych.

Słowa kluczowe: Krajowa Administracja Skarbowa, reforma, administracja podatkowa.

Summary: The subject of the article is the evaluation of the concept of reform of the fiscal apparatus introduced by the Act of 16 November 2016 on the National Revenue Administration. The assessment was made in relation to the fundamental problems that affected the tax and customs administration functioning until March 2017. This study seeks to answer the question: What arguments were in favor of the need to reform public finances in terms of rebuilding the fiscal apparatus? The article focuses on theoretical considerations, which the main purpose is the justification for the need to create the NRA, and to discuss the reasons that caused the reform of the fiscal apparatus. For the presentation of the discussed issues, the method of analysis of legal acts, statistics published by the tax authorities, press releases and scientific publications were used in the article.

Keywords: National Treasury Administration, reform, tax administration. 


\section{Wstęp}

Każda organizacja jest tworem dynamicznym, co oznacza, że nie mamy do czynienia $z$ raz na zawsze ustaloną strukturą, lecz ze strukturą ewoluującą, której zmiany są naturalnym następstwem procesów zachodzących zarówno w jej wnętrzu, jak i na zewnątrz. Dotyczy to również administracji danin publicznych, dla której otoczeniem zewnętrznym jest przede wszystkim system społeczno-gospodarczy, w tym będący jego elementem system podatkowy [Kulicki 2014a, s. 129]. Wobec tego funkcjonowanie administracji publicznej związane jest nieodłącznie z koniecznością zmian wynikających z dostosowywania się do otoczenia. Umiejętność właściwej reakcji na zapotrzebowanie otoczenia jest ważnym elementem prawidłowego działania każdej organizacji, w tym również administracji publicznej. Dynamicznie zmieniające się otoczenie, wprowadzenie nowych technologii w zakresie informacji i komunikacji, spowodowało konieczność dostosowania się dotychczasowej administracji podatkowej i celnej do tych wymagań. Funkcjonujące struktury administracji podatkowej oraz Służby Celnej nie spełniały wymogów stawianych nowoczesnej administracji. Służby te nie działały według jednolitych procedur, były rozproszone i powielały zadania związane z procesem poboru należności. Zapotrzebowanie na naprawę administracji podatkowej oraz Służby Celnej było sygnalizowane także przez obywateli. Podatnicy oczekiwali przyjaznej obsługi, szybszego załatwiania spraw w urzędzie oraz prostoty systemu podatkowego. Stąd najistotniejszą kwestią pozostaje reforma systemu podatkowego $\mathrm{w}$ celu wspierania przedsiębiorczości w poczuciu stabilizacji życia gospodarczego obywateli [Klonowska 2011, s. 54]. Istotna stała się reorientacja administracji publicznej, zwrócenie szczególnej uwagi na relacje i potrzeby podatnika. Strategia relacji z podatnikiem opiera się na informowaniu podatników o ich prawach i obowiązkach oraz na szczególnym traktowaniu pewnych grup podatników (osoby rozpoczynające działalność gospodarczą, absolwenci szkół średnich i wyższych, osoby niepełnosprawne, emeryci i renciści) [Biuletyn Informacyjny 2004, s. 7].

W świetle przedstawionych problemów - reforma administracji podatkowej i Służby Celnej jest odpowiedzią na istniejące niedoskonałości usług podatkowych i celnych świadczonych na rzecz społeczeństwa XXI wieku. Konsolidację obu służb podatkowej i celnej przeprowadzono zarówno na płaszczyźnie przedmiotowej, tj. w ramach Ministerstwa Finansów, jak i podmiotowej - w ramach resortu. Realizacją połączenia administracji podatkowej i Służby Celnej jest Ustawa z dnia 16 listopada 2016 r. o Krajowej Administracji Skarbowej (KAS).

Głównym celem niniejszego artykułu jest przeprowadzenie analizy administracji aparatu skarbowego w Polsce wraz z uzasadnieniem potrzeby jej reformy. Zwró- 
cono uwagę na budzącą spore kontrowersje koncepcję powołania KAS, która była różnie oceniana przez projektodawców, przedstawicieli rządu i innych ekspertów. W opracowaniu dokonano oceny funkcjonowania KAS. Analizie poddano wpływy budżetowe z tytułu podatków i cła oraz liczbę kontroli podatkowych.

W pierwszej części przedstawiono argumenty wskazujące na potrzebę przeprowadzenia zmian w administracji podatkowej oraz w Służbie Celnej. Omówiono niedoskonałości dotychczasowych struktur organizacyjnych, które przyczyniły się do reformy aparatu skarbowego. W części drugiej zaprezentowano kierunki działania KAS i wynikające z nich cele, sformułowane w oparciu o zarządzenie Ministra Rozwoju i Finansów w sprawie kierunków działania i rozwoju Krajowej Administracji Skarbowej na lata 2017-2020. Część trzecia zawiera podsumowanie wyników działalności KAS i ich ocenę. Analiza wyników stanowi odpowiedź na pytanie: Czy reforma przyniosła spodziewane efekty?

Przy pisaniu artykułu korzystano z wyników badań prowadzonych na portalu internetowym Bankier, informacji Ministerstwa Finansów oraz danych statystycznych ogłaszanych przez administrację skarbową. Do prezentacji omawianych zagadnień wykorzystano metodę analizy aktów prawnych, informacji prasowych oraz publikacji naukowych.

\section{Potrzeba i cele utworzenia Krajowej Administracji Skarbowej}

Administracja publiczna znajduje się w procesie nieustannej zmiany, ponieważ musi odpowiedzieć na wiele nowych potrzeb i żądań społeczeństwa. Dostosowywanie organizacji administracji publicznej do zmieniającego się otoczenia, w którym administracja publiczna wypełnia swoje zadania, musi być realizowane z zapewnieniem trwałości wykonywanych zadań publicznych oraz organizacyjnej spójności zmieniającego się systemu administracji publicznej w państwie [Izdebski 2007, s. 207]. Konieczność wprowadzania zmian organizacyjnych musi być analizowana łącznie z ujemnymi zjawiskami, które towarzyszą innowacjom takim, jak okresowy spadek sprawności funkcjonowania, wzrost kosztów administrowania, znużenie społeczeństwa [Jełowicki 1987, s. 306].

Wprowadzanie reform $\mathrm{w}$ administracji publicznej wiąże się $\mathrm{z}$ istotnymi zmianami $\mathrm{w}$ zakresie funkcjonowania organizacji, ponieważ zawsze łączy się z rozwiązywaniem konfliktów między koniecznością zapewnienia trwałości realizacji zadań a dostosowywaniem administracji publicznej do otoczenia, podnoszeniem jakości jej działania oraz rozwiązywaniem problemów związanych z wdrażaniem zmian, jak również jakością działania instytucji po zmianach [Izdebski 2007, s. 209]. Dlatego ważnym zagadnieniem nauki prawa administracyjnego, polityki administracyjnej i nauki administracji jest problematyka reform administracji publicznej [Leoński 2002, s. 53].

Pierwsze prace nad reformą ukształtowanej w latach 1983-1992 struktury organizacyjnej rządowej administracji danin publicznych podjęto w Ministerstwie Finan- 
sów już w 1998 r. Tymczasem idea reformy całej administracji danin publicznych, podporządkowanej Ministrowi Finansów, nastąpiła na przełomie lat 2005 i 2006.

Opracowany w tamtych latach w Ministerstwie Finansów projekt zmian zakładał powołanie Krajowej Administracji Skarbowej (KAS) w miejsce funkcjonujących wówczas Służby Celnej i administracji podatkowej. Konsolidacja służb celnych i podatkowych miała być przeprowadzona zarówno na szczeblu centralnym, obejmującym właściwe departamenty w Ministerstwie Finansów, jak i regionalnym i lokalnym przez połączenie izb skarbowych i izb celnych oraz urzędów skarbowych i urzędów celnych. W ich miejsce miały zostać utworzone: na poziomie regionalnym - izby administracji skarbowej, na poziomie lokalnym - urzędy administracji skarbowej.

W skład Krajowej Administracji Skarbowej miały wchodzić, obok już wymienionych jednostek organizacyjnych, również Krajowa Informacja Skarbowa, wykonująca zadania w zakresie informacji o przepisach prawa podatkowego i celnego, Krajowa Szkoła Skarbowości, odpowiadająca za szkolenia pracowników skarbowości, oraz Centrum Informatyki, wykonujące zadania w obszarze systemów informatycznych. Jednak przedstawiony projekt nie został zrealizowany.

$\mathrm{Na}$ gruncie administracji podatkowej wprowadzona w marcu 2017 r. reforma wiązała się z likwidacją służb celnych i skarbowych. Funkcjonujące dotychczas administracje: celna oraz podatkowa, nie odpowiadały wymaganiom stawianym przez społeczeństwo polskie. Wystąpiło zapotrzebowanie na zupełnie odmienny układ systemu administracji podatkowej oraz Służby Celnej. Kształtowanie kontaktów z podatnikiem stało się najważniejszym zadaniem strategicznym reformy administracji skarbowej.

Analiza problemów, które dotykały administrację podatkową i celną, pozwoli znaleźć odpowiedź na następujące pytania: Jakie argumenty przemawiały za przeprowadzeniem reformy? Czy naprawa administracji podatkowej oraz Służby Celnej była konieczna i dlaczego?

Odpowiedź na sformułowane pytania zostanie udzielona po uprzednim przybliżeniu okoliczności, które przyczyniły się do przeprowadzenia reformy aparatu skarbowego oraz przedstawieniu trzech najważniejszych argumentów dowodzących słuszności tej inicjatywy.

- Po pierwsze, dynamicznie zmieniające się otoczenie, rozwój i liberalizacja gospodarki, swobodny przepływ kapitału i osób, a także zmiana oczekiwań ze strony obywateli (zwłaszcza przedsiębiorców) wywołała konieczność dostosowania się administracji podatkowej i celnej do tych wymagań przez właściwe określenie celów działania i rozwoju oraz przystosowania nowej struktury do potrzeb gospodarki rynkowej.

- Po drugie, z danych Ministerstwa Finansów wynikało, że w szybkim tempie rosły zobowiązania egzekucyjne, czego dowodem była następująca informacja: „działaniem koniecznym było usprawnienie funkcjonowania aparatu skarbowego, rosnące zobowiązania egzekucyjne: w 2007 r. wynosiły ok. 20 mld zł, 
a obecnie przekraczają $65 \mathrm{mld}$ zł" [www.mf.gov.pl/de/ministerstwo-finanow...]. Zauważono coraz bardziej rozpowszechniające się zjawisko oszustw podatkowych, zwłaszcza dotyczących podatku od towarów i usług (VAT). Centrum Analiz i Studiów Podatkowych Szkoły Głównej Handlowej w Warszawie wskazało, że w dobie gospodarki globalnej Polska stanęła przed istotnymi problemami, m.in. uchylania się od opodatkowania i unikania opodatkowania zarówno w wymiarze wewnątrzkrajowym, jak i międzynarodowym. Koszty, jakie Polska płaci za brak umiejętnego i skutecznego przeciwdziałania i zwalczania tych zjawisk, są bardzo duże i szacuje się je na 80-100 mld zł rocznie. W związku z tym problem ograniczenia skali oszustw podatkowych i zwiększenie skuteczności poboru podatków i ceł przez reformę administracji skarbowej jest celem jak najbardziej słusznym [Gajewski, Nowak-Far 2016, s. 2].

Niepokój budziły również niektóre wskaźniki oceniające realizację przez organy skarbowe przypisanych im funkcji. W okresie ostatnich kilkunastu lat stan zaległości podatkowych wzrósł ponad dwukrotnie, z 4,7\% w 1998 r. do 10,91\% w 2012 r. [Kulicki 2014b, s. 4/15. Warto zaznaczyć, że w dokumencie programowym Kierunki rozwoju izb i urzędów skarbowych na lata 1999-2002 założono, że w 2002 r. stan zaległości wyniesie 3\% (z 6,04\% w 1995 r.) [Kierunki działania izb i urzędów]. Pogorszeniu uległy również wskaźniki egzekucji administracyjnej. Pod koniec lat 80. i na początku lat 90. XX wieku wskaźnik realizacji tytułów wykonawczych przekraczał $70 \%$; obecnie wynosi on ok. $40 \%$. W tym samym okresie znacznie zmniejszył się wskaźnik efektywności egzekucji. W 1990 r. wynosił 79,9\%, obecnie waha się od 20\% do 25\% [Kulicki 2014b, s. $4 / 15]$.

- Po trzecie, potrzebna była zmiana w działaniu służb odpowiedzialnych za ściąganie należności budżetowych. Istniejące dotychczas administracja podatkowa, skarbowa i Służba Celna posiadały strukturę rozproszoną, skupioną w trzech niezależnie funkcjonujących pionach:

- administracji podatkowej (16 izb skarbowych oraz 400 urzędów skarbowych),

- Służby Celnej (16 izb celnych, 45 urzędów celnych wraz z 143 oddziałami celnymi),

- kontroli skarbowej (16 urzędów kontroli skarbowej, 8 zamiejscowych ośrodków urzędów kontroli skarbowej) [www.mf.gov.pl].

Zadania tych służb często powielały się, co prowadziło do mniejszej sprawności i większych kosztów. Każdy organ (urzędy skarbowe, urzędy kontroli skarbowej i urzędy celne) miał swoje oddzielne systemy informatyczne, co utrudniało szybką wymianę danych. Podział aparatu skarbowego na trzy odrębne piony: podatkowy, celno-akcyzowy i kontrolny, miał również swoje negatywne implikacje w wypełnianiu przez Ministra Finansów funkcji programowania danin publicznych oraz projektowania i tworzenia prawa daninowego. Wewnątrz Ministerstwa Finansów nie istniało $\mathrm{w}$ tym zakresie jednolite kierownictwo. Za politykę podatkową oraz legi- 
slację podatkową odpowiadał nie tylko członek kierownictwa Ministerstwa Finansów, któremu podlegały departamenty podatkowe (Polityki Podatkowej, Podatków Dochodowych, Podatku od Towarów i Usług, Podatków Lokalnych), ale również Szef Służby Celnej, któremu podlegał Departament Podatku Akcyzowego i Gier, do którego przypisano zagadnienia z zakresu podatków: akcyzowego, ekologicznego, od gier oraz od wydobycia niektórych kopalin. Utworzenie w Ministerstwie Finansów trzech ośrodków decyzyjnych odpowiedzialnych za organizację i kierowanie wykonywaniem przez organy skarbowe funkcji rejestracyjnej, wymiarowej, weryfikacyjnej, kontrolnej, poboru, windykacyjnej, dochodzeniowo-śledczej, prewencyjnej i informacyjnej doprowadziło do istotnych różnic organizacyjnych w zakresie zarząazzania kadrami oraz podstaw prawnych działania poszczególnych jednostek organizacyjnych [Kulicki 2014a, s. 18-20].

W obszarze zarządzania poborem danin publicznych nieprawidłowości dotyczące wewnętrznej organizacji aparatu skarbowego należało zniwelować poprzez połączenie odrębnych struktur. Koncepcja podporządkowania wszystkich dotychczasowych struktur skarbowych jest co do zasady słusznym rozwiązaniem wtedy, gdy gwarantuje również nową jakość w zakresie koordynacji działań tych wszystkich elementów składowych [Gajewski, Nowak-Far 2016, s. 7].

J. Kulicki spostrzegł także inne problemy, które dotykały polską administrację skarbową i rodziły poważne następstwa dla wykonywania prawa podatkowego przez organy skarbowe i podatników. Zauważa, że ukształtowanie aparatu wykonawczego według kryterium rodzaju podatku, a nie w oparciu o realizowane funkcje, prowadzi do wielości organów skarbowych, a w konsekwencji do wielości unormowań ustrojowych, pracowniczych, proceduralnych, wewnętrznych regulacji, nakładania się kompetencji i wzajemnej rywalizacji. Poza tym zwraca uwagę, że obecna struktura organizacyjna aparatu podporządkowanego ministrowi właściwemu do spraw finansów publicznych jest typowym przykładem struktury kastowej, w której poszczególne części (podatkowa, kontrolna i celno-akcyzowa) działają w oderwaniu od siebie, aczkolwiek prawne regulacje w tym zakresie zobowiązują je do współdziałania (współpracy) [Kulicki 2016, s. 20].

W świetle przedstawionych interpretacji, dotychczasowe organy administracji podatkowej realizowały odrębne kierunki rozwoju, miały inne cele strategiczne oraz ustalały różne mierniki ich realizacji. Zasady ich funkcjonowania były określone w odrębnych ustawach. Przepisy prawne dla tych organów regulowały następujące ustawy (z chwilą powołania KAS zostały uchylone):

- Ustawa z dnia 28 września 1991 r. o kontroli skarbowej,

- Ustawa z dnia 21 czerwca 1996 r. o urzędach i izbach skarbowych,

- Ustawa z dnia 27 sierpnia 2009 r. o Służbie Celnej,

- Ustawa z dnia 10 lipca 2015 r. o administracji podatkowej.

Ustawodawca uznał, iż tego typu rozproszenie, połączone z powielaniem niektórych zadań związanych z procesem poboru należności podatkowych i celnych w ramach poszczególnych służb (np. kontrola prawidłowości realizacji obowiązków 
podatkowych i celnych, postępowanie egzekucyjne), wywołuje brak spójnego i jednolitego działania oraz optymalnego wykorzystania dostępnej kadry oraz zasobów organizacyjnych i finansowych [Uzasadnienie do projektu z dnia 17 lutego 2016].

Nie można pominąć również opinii przedstawicieli rządu, którzy w trakcie prac nad projektem ustawy o Krajowej Administracji Skarbowej na temat struktury administracji podatkowej wyrazili następujące zdanie: „Obecnie służby te działają w modelu rozproszonym. Każda z nich ma niezależne systemy informatyczne, bazy danych są rozproszone i nie ma bieżącej wymiany informacji między nimi. Celem powołania nowej struktury ma być zwiększenie wpływów do budżetu, uszczelnienie systemu podatkowego, zmniejszenie biurokracji i przeniesienie części pracowników do pomocy podatnikom i przedsiębiorcom" [www.inforfk.pl].

Poza tym negatywne cechy dotychczasowej struktury administracji podatkowej dostrzegane były również przez projektodawców ustawy o KAS. W uzasadnieniu do projektu z dnia 17 lutego 2016 r. ustawy o Krajowej Administracji Skarbowej wymieniono między innymi: rozproszenie i powielanie niektórych zadań związanych z procesem poboru należności podatkowych i celnych w ramach poszczególnych służb, podleganie różnym procedurom kontroli prowadzonych wobec podmiotów, wysokie koszty administracyjne poboru podatków: w Polsce 1,6\%, w Hiszpanii 0,67\%.

W ostatnich latach podejmowano próby zmierzające do integracji systemów informatycznych, a także konsolidacji procesów pomocniczych, danych rejestracyjnych i podatkowych pomiędzy poszczególnymi jednostkami organów skarbowych. Mimo to zainicjowane działania nie przyniosły zamierzonego celu. W dalszym ciągu zadania wykonywane przez organy były wspierane przez odrębne systemy informatyczne, a bazy danych rozproszone na poziomie lokalnym, przez co nie było możliwe pełne wykorzystanie zgromadzonych danych podatkowych do przeprowadzania bieżących analiz służących do wykrywania i eliminacji błędów oraz oszustw podatkowych. Oprócz tego zarządzanie poszczególnymi obszarami zadań na poziomie centralnym było podzielone między kilka organów nadzorowanych przez Ministra Finansów.

Reasumując, funkcjonująca struktura administracji podatkowej od ponad trzydziestu lat (z pewnymi modyfikacjami) nie spełniała wymogów stawianych nowoczesnej administracji. Utrudniała oraz uniemożliwiała spójne i skuteczne wykonywanie zadań. Niejednolite zarządzanie i rozproszona struktura służb celnych i podatkowych ułatwiały istnienie tzw. szarej strefy. Nierównomierność rozmieszczenia w terenie izb i urzędów celnych oraz skarbowych, różnorodność wyposażenia w budynki, sprzęt i zasoby ludzkie powodowała zróżnicowanie finansowania i nieczytelność zarządzania majątkiem, zasobami ludzkimi, sprzętem i systemami informatycznymi. Taka dysproporcja organizacyjna prowadziła do braku standaryzacji pracy izb i urzędów celnych oraz skarbowych.

Przedstawione argumenty zadecydowały o przeprowadzeniu konsolidacji służb administracji podatkowej i Służby Celnej w Krajową Administrację Skarbową (KAS). 
W następstwie tego z dniem 1 marca 2017 r. powołano jednolitą Krajową Administrację Skarbową na mocy przepisów ustawy z dnia 16 listopada 2016 r. o Krajowej Administracji Skarbowej oraz ustawy Przepisy wprowadzające ustawę o Krajowej Administracji Skarbowej. Nowa ustawa określa administrację skarbową jako wyspecjalizowaną administrację rządową wykonującą zadania z zakresu realizacji dochodów z tytułu podatków, należności celnych, opłat oraz niepodatkowych należności budżetowych, ochrony interesów Skarbu Państwa oraz ochrony obszaru celnego Unii Europejskiej, a także zapewniającą obsługę i wsparcie podatnika i płatnika w prawidłowym wykonywaniu obowiązków podatkowych oraz obsługę i wsparcie przedsiębiorcy w prawidłowym wykonywaniu obowiązków celnych [Ustawa z 16 listopada 2016].

Na skutek wprowadzenia KAS zlikwidowane zostały urzędy kontroli skarbowej oraz urzędy i izby celne. Jednocześnie zniesione zostały urzędy Generalnego Inspektora Kontroli Skarbowej oraz Szefa Służby Celnej. Izba Skarbowa kontynuuje działalność jako Izba Administracji Skarbowej. Reforma tych służb stoi przed wyzwaniem efektywniejszego zaspokajania potrzeb klientów. Celem jej jest przede wszystkim poprawa jakości świadczonych usług na rzecz obywatela, jak również polepszenie sprawności działania oraz skuteczności i efektywności całej administracji skarbowej. Struktury powoływane w wyniku reformy będą musiały przede wszystkim ograniczyć zjawisko luki podatkowej (zwłaszcza w podatku od towarów i usług) oraz zapewnić skuteczną kontrolę uiszczania przez podatników należności podatkowych [Kosińska, Ruśkowski, Woltanowski 2016, s. 18]. Tym samym strategia podatkowa koncentruje się wokół skutecznego, efektywnego i sprawiedliwego pobierania dochodów budżetowych, skutecznej walki z nadużyciami systemu podatkowego, zapewnienia lepszej obsługi podatnikom, ułatwienia legalnej działalności gospodarczej, usuwania barier biurokratycznych oraz doskonalenia standardów działania i rozwoju infrastruktury, która odpowiada współczesnym wyzwaniom i oczekiwaniom społeczeństwa [Fiuk 2005, s. 2, 4, 5].

Szef Krajowej Administracji Skarbowej odnośnie do reformy administracji podatkowej stwierdził: „Dążymy do ciągłej poprawy jakości obsługi naszych interesariuszy - podatników i przedsiębiorców (...) połączenie trzech administracji w jedną pozwoli na lepsze wykorzystanie ich możliwości, przynosząc korzyści, zarówno z punktu widzenia podatników, jak również z punktu widzenia naszego budżetu (...). Wdrażając Krajową Administrację Skarbową szczególnie dbamy o komfort i bezpieczeństwo naszych podatników” [www.tvsierpc.pl]. „Aby mówić o nowoczesnej administracji skarbowej, skutecznej, świadomej stawianych przed nią oczekiwań i zdolnej te oczekiwania realizować, konieczne było wprowadzenie zmian organizacyjnych, w wyniku których służby wcześniej działające niezależne od siebie, od 1 marca 2017 r. zaczęły funkcjonować jako jedna struktura" [www.mf.gov.pl].

W wykazie prac legislacyjnych i programowych Rady Ministrów przedstawiciele rządu wyrazili następującą opinię: „Celem ustawy o Krajowej Administracji Skarbowej jest między innymi optymalizacja poboru danin publicznych oraz pełna 
realizacja założonych zamierzeń fiskalnych państwa (...). Podstawowym uzasadnieniem reformy jest skrócenie postępowań, co wychodzi naprzeciw oczekiwaniom podatników wielokrotnie skarżących się na ich przewlekłość" [www.wpolityce.pl ].

Konkludując, w uzasadnieniu do projektu z dnia 17 lutego 2016 r. ustawy o Krajowej Administracji Skarbowej czytamy, że zaproponowany model Krajowej Administracji Skarbowej umożliwi:

- usprawnienie obsługi podatnika, w tym także obsługi i wsparcia podatnika oraz przedsiębiorcy w prawidłowym wykonywaniu obowiązków podatkowych i celnych,

- efektywny pobór podatków,

- skuteczną egzekucję należności pieniężnych,

- zmniejszenie luki podatkowej,

- poprawę skuteczności i efektywności w zwalczaniu oszustw podatkowych i odzyskiwaniu zaległości podatkowych i celnych,

- jednolite orzecznictwo w sprawach podatkowych i celnych na terenie całego kraju,

- efektywną, tzn. rzetelną i szybką weryfikację danych podawanych przez podatników w deklaracjach podatkowych i dokumentach celnych,

- zwiększenie efektywności i skuteczności kontroli wywiązywania się przez podatników z zobowiązań podatkowych,

- sprawny przepływ informacji,

- lepszą współpracę między sobą wszystkich organów administracji skarbowej,

- usprawnienie systemu doboru kadry, jej kształcenia i motywowania,

- stworzenie jednolitego systemu zbierania i analizowania danych,

- usprawnienie systemu zapewniającego bezpieczeństwo finansowe państwa,

- poprawę wizerunku administracji skarbowej [Uzasadnienie do projektu z 17 lutego 2016, s. 7].

Warto zaznaczyć, że wcześniej wprowadzane fragmentarycznie zmiany w strukturze aparatu skarbowego nie były poprzedzane badaniami naukowymi, w tym przede wszystkim trafnym wskazaniem wyzwań, jakie stały przed aparatem skarbowym, oraz błędów i czynników ograniczających efektywność, które trzeba w wyniku reformy wyeliminować [Kosińska, Ruśkowski, Woltanowski 2016, s. 18].

Krajowej Administracji Skarbowej w wyniku przeprowadzonej reformy powierzono nowe zadania. Realizacja zadań określonych dla KAS odbywa się w oparciu o dokument Kierunki dziatania i rozwoju Krajowej Administracji Skarbowej na lata 2017-2020 [Dziennik Urzędowy Ministra Rozwoju i Finansów z 2 sierpnia 2017].

\section{Kierunki dzialania i rozwoju Krajowej Administracji Skarbowej}

Oczekiwania i potrzeby podatnika stanowią centrum zainteresowania oraz podstawę wprowadzania usprawnień i zmian w tym zakresie. Ważne stały się wartości ofe- 
rowane podatnikom: dostępność, nowoczesność i użyteczność usług oraz wysoka jakość obsługi. Obecnie w administracji skarbowej zmienił się sposób wykonywania zadań i świadczenia usług - w kierunku biznesowego, proklienckiego podejścia i zarząadzania. Stąd już poprzednia administracja podatkowa i skarbowa oraz Służba Celna podejmowały działania ukierunkowane na poprawę jakości usług na rzecz podatnika. Jednakże działania te utrudniały odrębne kierunki rozwoju i niekompatybilne systemy informatyczne. W konsekwencji powodowało to rozproszoną i niespójną realizację zadań w zakresie poboru podatków i ceł.

Dla zapewnienia skutecznej i efektywnej realizacji zadań Krajowej Administracji Skarbowej oraz wysokiej jakości jej działania w dniu 25 lipca 2017 r. zostało podpisane zarządzenie Ministra Rozwoju i Finansów w sprawie kierunków działania i rozwoju Krajowej Administracji Skarbowej na lata 2017-2020 [Zarządzenie Ministra Rozwoju i Finansów z 25 lipca 2017]. Dokument ten jest strategią, która odpowiada za aktualny pobór danin publicznych do budżetu państwa, wychodzi również naprzeciw oczekiwaniom społeczeństwa wobec administracji skarbowej [www. mf.gov.pl]. Szef Krajowej Administracji Skarbowej zaznaczył: „Koncentrujemy się na wzmocnieniu zaufania i budowaniu trwałych, dobrych relacji między Krajową Administracją Skarbową a podatnikami, w tym przedsiębiorcami. Temu właśnie służy wyznaczenie czteroletnich kierunków działania i rozwoju. Realizacja tych założeń pozwoli skutecznie wykonywać zadania Krajowej Administracji Skarbowej oraz zagwarantuje wysoką jakość jej działania" [www.mf.gov.pl]. Zarządzenie w sprawie kierunków działania i rozwoju Krajowej Administracji Skarbowej na lata 2017-2020 określa misję i wizję administracji skarbowej oraz cele, do których wskazane są plany działania.

Misją Krajowej Administracji Skarbowej jest zapewnienie stabilnych, efektywnych i zrównoważonych finansów publicznych oraz wysokiej jakości świadczonych usług [Zarządzenie Ministra Rozwoju i Finansów z 25 lipca 2017].

Należy zauważyć, że specyfika misji administracji podatkowej wkracza w strefę indywidualnych interesów obywateli, co często powoduje konfliktogenne spory pomiędzy podatnikiem a organem podatkowym. Sytuacja taka prowadzi do antypatii w stosunkach między organami podatkowymi, co w znacznym stopniu może utrudniać realizację celu [Kasperowicz-Stępień 2004, s. 561-562].

Wizja Krajowej Administracji Skarbowej została przedstawiona jako nowoczesna, skuteczna w egzekwowaniu podatków oraz ciesząca się zaufaniem społecznym organizacja, wspierająca uczciwych podatników i przedsiębiorców, zwalczająca oszustwa podatkowe i celne oraz chroniąca rynek i społeczeństwo [Zarządzenie Ministra Rozwoju i Finansów z 25 lipca 2017].

Kierunki działania i rozwoju Krajowej Administracji Skarbowej są spójne z założeniami przyjętej przez Radę Ministrów Strategii na rzecz Odpowiedzialnego Rozwoju, która jest głównym dokumentem strategicznym kraju [Uchwała nr 8 z 14 lutego 2017]. Kierunki działania i rozwoju Krajowej Administracji Skarbowej na lata 2017-2020 przedstawia rysunek 1. 


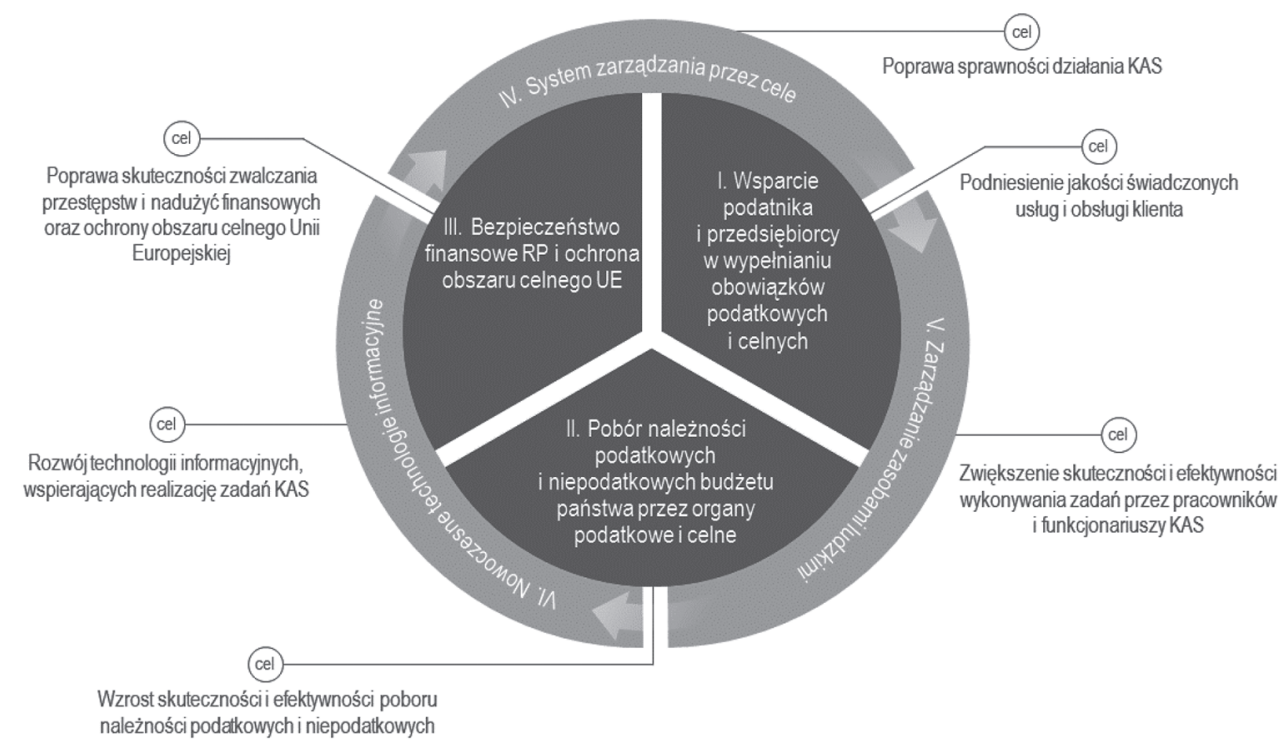

Rys. 1. Kierunki działania i rozwoju Krajowej Administracji Skarbowej na lata 2017-2020

Źródło: opracowanie własne na podstawie [Zarządzenie Ministra Rozwoju i Finansów z 25 lipca 2017].

Zarządzenie w sprawie kierunków działania i rozwoju Krajowej Administracji Skarbowej określa poszczególne cele, wskazując jednoznacznie działania podejmowane przez organy administracji skarbowej. Plany działania sformułowane w Zarządzeniu Ministra Rozwoju i Finansów z dnia 25 lipca 2017 r. przedstawia rysunek 2.

Zgodnie z zaprezentowaną strategią do 15 marca każdego roku Szef Krajowej Administracji Skarbowej przedstawia raport ze stanu realizacji celów i działań określonych w dokumencie, które zostały podjęte w poprzednim roku. Raport zawiera w szczególności informację o stopniu osiągnięcia wartości wskaźników oraz ewentualne propozycje działań służące zapewnieniu skutecznej realizacji założeń dokumentu.

Najważniejszymi spodziewanymi korzyściami przyjęcia czteroletnich kierunków działania i rozwoju Krajowej Administracji Skarbowej są:

- wzrost satysfakcji klientów Krajowej Administracji Skarbowej oraz wzmocnienie zaufania do państwa i jego instytucji,

- skrócenie czasu, jaki przedsiębiorca przeznacza na wypełnianie obowiązków podatkowych,

- ograniczenie przestępczości gospodarczej,

- zmniejszenie luki w podatku VAT,

- zmniejszenie kosztów poboru podatków [www.mf.gov.pl].

Mając na uwadze skuteczność realizacji Kierunków działania i rozwoju Krajowej Administracji Skarbowej, raz w roku przeprowadzana jest ewaluacja dokumentu. Jej 

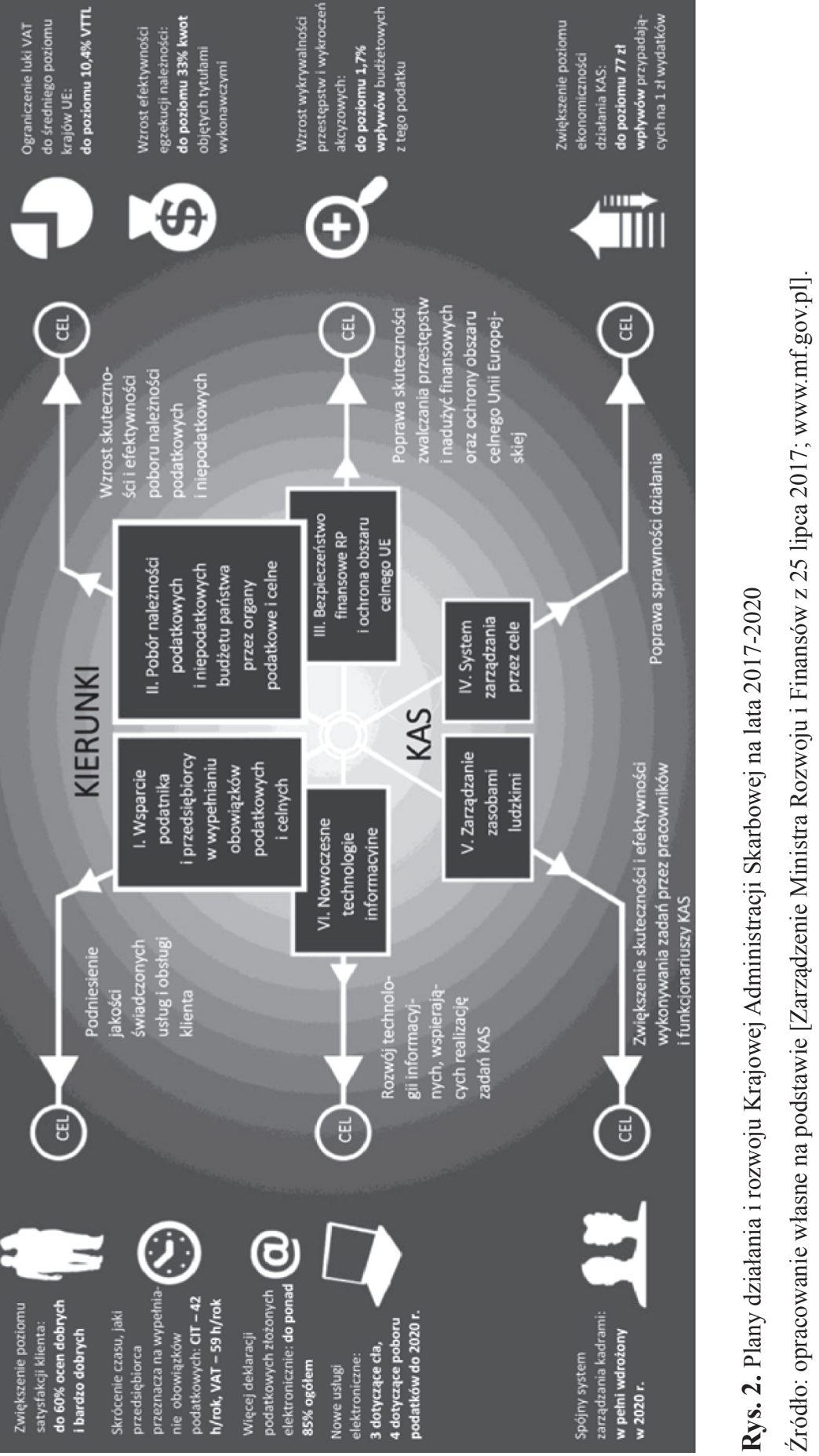
wyniki stanowią rekomendacje do dokonania ewentualnych zmian w dokumencie. Proces ten jest niezbędny do tego, aby działania KAS mogły sprostać zmieniającym się uwarunkowaniom zewnętrznym oraz oczekiwaniom społecznym. Ocenie podlega przede wszystkim spójność dokumentu z aktualnymi celami strategicznymi państwa, wskazanymi w obowiązujących dokumentach o charakterze strategicznym, tj. Strategii na rzecz Odpowiedzialnego Rozwoju [Uchwała nr 8 z 14 lutego 2017] oraz Wieloletnim Planie Finansowym Państwa [Uchwała nr 46 z 25 kwietnia 2017].

\section{Wpływ reformy na efektywność i skuteczność Krajowej Administracji Skarbowej}

Efekty i skutki wprowadzenia reformy aparatu skarbowego zostały zaprezentowane na podstawie wpływów budżetowych z tytułu podatków i cła oraz liczby kontroli podatkowych.

\subsection{Wplywy budżetowe $\mathrm{z}$ tytułu podatków i cla}

Wpływy budżetowe z tytułu podatków i cła według stanu na dzień 31 grudnia 2015 r., 2016 r. i 2017 r. przedstawia tabela 1.

Tabela 1. Wpływy budżetowe z tytułu podatków i cła według stanu na 31 grudnia 2015 r., 2016 r. i 2017 r.

\begin{tabular}{|c|c|c|c|c|c|c|c|}
\hline \multirow{2}{*}{ Wyszczególnienie } & \multirow{2}{*}{$\begin{array}{l}\mathrm{I}-\mathrm{XII} \\
2015\end{array}$} & \multirow{2}{*}{$\begin{array}{l}\text { I-XII } \\
2016\end{array}$} & \multirow{2}{*}{$\begin{array}{l}\text { I-XII } \\
2017\end{array}$} & \multicolumn{2}{|c|}{ Różnica } & \multicolumn{2}{|c|}{ Dynamika } \\
\hline & & & & $2016-2015$ & $2017-2016$ & $2016 / 2015$ & $2017 / 2016$ \\
\hline $\begin{array}{l}\text { Podatek } \\
\text { dochodowy od } \\
\text { osób prawnych }\end{array}$ & 25812 & 26381 & 29761 & 569 & 3380 & $102,20 \%$ & $112,81 \%$ \\
\hline $\begin{array}{l}\text { Podatek } \\
\text { dochodowy od } \\
\text { osób fizycznych }\end{array}$ & 45040 & 48232 & 52667 & 3192 & 4435 & $107,09 \%$ & $109,19 \%$ \\
\hline $\begin{array}{l}\text { Podatek od } \\
\text { towarów i usług }\end{array}$ & 123121 & 126584 & 156801 & 3463 & 30217 & $102,81 \%$ & $123,87 \%$ \\
\hline Podatek akcyzowy & 62809 & 65749 & 68261 & 2940 & 2512 & $104,68 \%$ & $103,82 \%$ \\
\hline Podatek od gier & 1337 & 1407 & 1640 & 70 & 233 & $105,23 \%$ & $116,56 \%$ \\
\hline $\begin{array}{l}\text { Podatek od } \\
\text { wydobycia } \\
\text { niektórych kopalin }\end{array}$ & 1553 & 1277 & 1786 & -276 & 509 & $82,20 \%$ & $139,87 \%$ \\
\hline $\begin{array}{l}\text { Podatek od } \\
\text { niektórych } \\
\text { instytucji } \\
\text { finansowych }\end{array}$ & & 3507 & 4341 & 3507 & 834 & & $123,79 \%$ \\
\hline Cło & 2929 & 3178 & 3556 & 249 & 378 & $108,50 \%$ & $111,88 \%$ \\
\hline Ogółem & 262602 & 276316 & 313814 & 13714 & 42498 & $105,22 \%$ & $115,38 \%$ \\
\hline
\end{tabular}

Źródło: opracowanie własne na podstawie [www.mf.gov.pl]. 
Dochody pobrane przez KAS w 2017 r. z tytułu podatków stanowiących dochód budżetu państwa oraz cła były wyższe w porównaniu $\mathrm{z}$ dochodami uzyskanymi w 2016 r. o około 42,5 mld zł, tj. o ponad 15\%. Wzrost wpływów nastąpił we wszystkich rodzajach podatków, a najwyższy wzrost odnotowano w podatku od towarów i usług (VAT).

Według danych Ministerstwa Finansów w 2017 r. nastąpił wzrost konsumpcji oleju napędowego w stosunku do 2016 r. o około $15 \%$, co daje około 4 mld zł dodatkowych wpływów z podatku VAT [www.mf.gov.pl].

Największe wpływy budżetowe pochodzą z akcyzy - efekt fiskalny został osiągnięty głównie na skutek rozwiązania pakietu paliwowego, tj. w 2017 r. około 4 mld zł dodatkowych wpływów z podatku VAT [www.wgospodarce.pl].

Nowe regulacje prawne dotyczące obrotu paliwami pozwoliły branży paliwowej osiągnąć rekordowe poziomy sprzedaży paliw, które do tej pory nie były notowane w Polsce. W pierwszych trzech miesiącach od wprowadzenia pakietu paliwowego odnotowano gwałtowny wzrost legalnej sprzedaży paliw płynnych. W sierpniu $2016 \mathrm{r}$. według Polskiej Organizacji Przemysłu i Handlu Naftowego nastąpił skokowy wzrost sprzedaży paliw o $29 \%$, we wrześniu o $26 \%$, a w październiku o $17 \%$ w porównaniu $\mathrm{z}$ analogicznymi okresami z poprzedniego roku [www.bankier.pl].

\subsection{Liczba kontroli podatkowych}

Liczbę kontroli podatkowych z podziałem na wielkość podmiotów, u których przeprowadzano kontrolę w okresie 2015-2017, przedstawia tabela 2.

W 2017 r. przeprowadzono o ponad 20 tysięcy kontroli mniej w stosunku do 2016 r. Najwięcej kontroli prowadzonych było w mikroprzedsiębiorstwach, a dotyczyły one podatku od towarów i usług oraz podatku dochodowego od osób fizycznych.

Według danych Ministerstwa Finansów, w 2017 r. efektywność kontroli podatkowych, liczona stosunkiem liczby kontroli zakończonych do liczby kontroli, w których stwierdzono nieprawidłowości, wyniosła $86 \%$ i była większa niż w 2016 r. Czas trwania kontroli został skrócony średnio o 10 dni, tj. średni czas trwania kontroli w 2017 r. wynosił do 45 dni. W wyniku kontroli prowadzonych przez urzędy celno-skarbowe (po reformie) realne wpłaty w 2017 r. wyniosły 1,74 mld zł. Wpłaty w wyniku kontroli zrealizowanych w 2016 r. przez urzędy kontroli skarbowej (przed reformą) wynosiły $1,16 \mathrm{mld}$ zł.

W 2017 r. widoczny jest wzrost o 50\% wpłat do budżetu, będących wynikiem kontroli prowadzonych przez nowe organy skarbowe. Ponadto wartość dodatkowych wpływów budżetowych wynikających z działań kontrolnych Krajowej Administracji Skarbowej w 2017 r. wynosiła ponad 3,35 mld zł. Dodatkowe wpływy były większe od zakładanych o 43,9\%. W okresie 1.03.2017-30.06.2017 nastąpił wzrost ściągalności podatków [www.mf.gov.pl] w następujących wysokościach:

- podatku VAT o 17,5 mld zł, 


\begin{tabular}{|c|c|c|c|c|c|c|c|c|}
\hline \multirow{4}{*}{$\stackrel{\bar{c}}{\vec{c}}$} & \multirow{3}{*}{$\begin{array}{l}\ddot{\Xi} \\
\stackrel{\Xi}{\xi} \\
\dot{3}\end{array}$} & 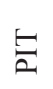 & $\frac{1}{n}$ & $\begin{array}{l}\text { ț } \\
\stackrel{n}{n}\end{array}$ & D & $\sim$ & $\underset{m}{\stackrel{9}{m}}$ & $\begin{array}{l}\stackrel{2}{0} \\
\text { ర0 }\end{array}$ \\
\hline & & 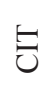 & $\underset{b}{\infty}$ & 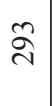 & $\Xi$ & ஜ & 0 & $\begin{array}{l}\stackrel{\infty}{\beth} \\
-\end{array}$ \\
\hline & & 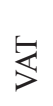 & $\begin{array}{l}\hat{\sigma} \\
\hat{0}\end{array}$ & $\begin{array}{l}\stackrel{\circ}{\sim} \\
\sim\end{array}$ & $\overrightarrow{\mathbb{N}}$ & $\stackrel{\circ}{\stackrel{+}{\sim}}$ & 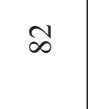 & $\begin{array}{l}\infty \\
\check{n} \\
m\end{array}$ \\
\hline & 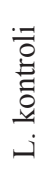 & 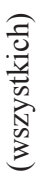 & $\begin{array}{l}\begin{array}{l}0 \\
0 \\
0 \\
I\end{array}\end{array}$ & $\begin{array}{l}\cong \\
\exists\end{array}$ & $\stackrel{\text { 巳 }}{\Xi}$ & $\begin{array}{l}\stackrel{8}{n} \\
m\end{array}$ & \& & $\begin{array}{l}\vec{\infty} \\
\stackrel{\sim}{\sim}\end{array}$ \\
\hline \multirow{4}{*}{$\begin{array}{l}0 \\
\stackrel{\sim}{\sim} \\
\sim\end{array}$} & & 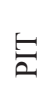 & $\begin{array}{l}\stackrel{2}{尺} \\
\end{array}$ & $\underset{\sigma}{\alpha}$ & ஜ & & $\underset{0}{\mathscr{O}}$ & $\begin{array}{l}\hat{\delta} \\
\stackrel{n}{2} \\
\simeq\end{array}$ \\
\hline & $\begin{array}{l}\ddot{\dot{E}} \\
\stackrel{\Xi}{\Xi} \\
3\end{array}$ & $\Xi$ & \begin{tabular}{l}
\multirow{\infty}{*}{} \\
$\stackrel{n}{-}$
\end{tabular} & $\stackrel{\infty}{+}$ & $\begin{array}{l}\stackrel{\sim}{\sim} \\
\stackrel{+}{*}\end{array}$ & $\stackrel{\sim}{\dot{f}}$ & $\sim$ & $\begin{array}{l}n \\
0 \\
m\end{array}$ \\
\hline & & $\underset{\$}{\stackrel{5}{\lessgtr}}$ & $\begin{array}{l}\stackrel{8}{D} \\
\stackrel{\sim}{\sim}\end{array}$ & $\begin{array}{l}\infty \\
i n \\
m\end{array}$ & 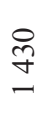 & $\widehat{\widehat{\sigma}}$ & 옴 & $\begin{array}{l}\frac{n}{n} \\
\stackrel{n}{N}\end{array}$ \\
\hline & 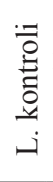 & 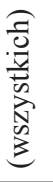 & $\begin{array}{l}n \\
\stackrel{n}{n} \\
m\end{array}$ & $\begin{array}{l}\infty \\
0 \\
+ \\
b\end{array}$ & $\frac{\tilde{\infty}}{\sim}$ & ષ্ & $\frac{\infty}{a}$ & $\begin{array}{l}\infty \\
\dot{8} \\
\dot{J} \\
\forall\end{array}$ \\
\hline \multirow{4}{*}{$\stackrel{n}{\frac{n}{2}}$} & \multirow{3}{*}{$\underset{3}{\stackrel{\text { 空 }}{3}}$} & 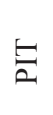 & 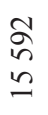 & 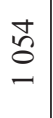 & $\infty$ & $r$ & $\hat{0}$ & $\begin{array}{l}\infty \\
\stackrel{2}{\wedge} \\
=\end{array}$ \\
\hline & & 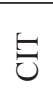 & $\underset{\sim}{\stackrel{ \pm}{\sim}}$ & $\bar{\triangleright}_{\infty}$ & 곤 & 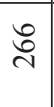 & - & $\begin{array}{l}\forall \\
\infty \\
m\end{array}$ \\
\hline & & $\underset{5}{\stackrel{5}{\lessgtr}}$ & $\begin{array}{l}\underset{ \pm}{ \pm} \\
\stackrel{ల}{\infty}\end{array}$ & \begin{tabular}{l}
\multirow{f}{*}{} \\
$\forall$
\end{tabular} & $\stackrel{\text { ๖ }}{-}$ & $\frac{0}{6}$ & $\underset{\mathbb{N}}{\stackrel{N}{ }}$ & $\begin{array}{l}\text { a } \\
\text { in } \\
\text { m }\end{array}$ \\
\hline & 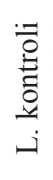 & 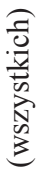 & 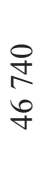 & $\begin{array}{l}\stackrel{\overbrace{}}{6} \\
\sim\end{array}$ & $\begin{array}{l}\stackrel{\infty}{N} \\
\sim\end{array}$ & $\frac{n}{a}$ & $\stackrel{\mathscr{g}}{\underset{I}{-}}$ & \begin{tabular}{l} 
巳 \\
\multirow{7}{*}{} \\
ò
\end{tabular} \\
\hline$\frac{\breve{c}}{\mathscr{2}}$ & $\begin{array}{l}0 \\
0 \\
0 \\
0 \\
0 \\
0 \\
0 \\
3\end{array}$ & 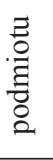 & 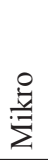 & $\frac{2}{\pi}$ & 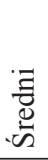 & 胥 & 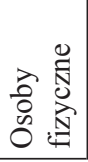 & 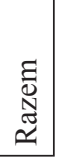 \\
\hline
\end{tabular}


- należności z tytułu akcyzy o 5\%,

- podatku dochodowego od osób prawnych o $14 \%$.

Realizacja wpływów podatkowych do budżetu państwa w 2017 r. wskazuje na dużą skuteczność działania zreformowanej administracji skarbowej. Wyższe wpływy do budżetu to między innymi efekt działań organów Krajowej Administracji Skarbowej, zmierzających do efektywnego poboru należności podatkowych i poprawy ściągalności podatków oraz ograniczania szarej strefy, która w znaczący sposób uszczuplała wpływy budżetowe. Portal informacji i opinii o stanie gospodarki podał: „Dzięki działaniom KAS polska szara strefa za IV kwartał 2017 skurczyła się do poziomu $12,7 \%$. Jeszcze rok temu wielkość szarej strefy w Polsce oceniano na $19 \%$ PKB" [wgospodarce.pl].

Działania Krajowej Administracji Skarbowej przełożyły się na uszczelnienie systemu podatkowego - wynikiem są wpływy z podatku VAT $(30 \mathrm{mld}$ zł w skali roku) oraz z tytułu podatku dochodowego od osób fizycznych (ponad $4 \mathrm{mln}$ w skali roku) [wgospodarce.pl].

Najwyższa Izba Kontroli w wystąpieniu pokontrolnym sporządzonym za 2017 r. podała: „dochody podatkowe wyniosły 315,3 mld zł, tj. 104,7\% wielkości planowanej. Prognoza dochodów podatkowych była oparta na rzetelnej analizie danych o wykonaniu dochodów za 2016 r. oraz spójnych założeniach oddziaływania - na wielkość wpływów - sytuacji gospodarczej i zmian systemowych. Prognozę przekroczono, bo wyższe, niż planowano, były dochody z tytułu podatku od towarów i usług (VAT). To główne źródło dochodów kasy państwa, dały one aż 156,8 mld zł. W porównaniu z $2016 \mathrm{r}$. dochody były wyższe o 30,2 mld zł, tj. o 23,9\%" [www. wyborcza.pl].

\section{Zakończenie}

Realizowana od 2017 r. reforma, tworząca Krajową Administrację Skarbową, dyktowana jest przede wszystkim potrzebą ochrony interesu ogólnego. Podjęto ją z myślą o ograniczeniu luki podatkowej [Kosińska, Ruśkowski, Woltanowski 2014, s. 170 i n.], której wielkość i ciągłe powiększanie się zagrażało już realnie stabilności finansów publicznych.

W świetle przedstawionych zagadnień reforma służb skarbowych stanowi jednolity model zarządzania wszystkimi zadaniami i całą strukturą terenową z poziomu centralnego, gdzie podstawową rolę zarządczą pełni Szef Krajowej Administracji Skarbowej wraz z zastępcami.

W wyniku reformy administracja skarbowa dostosowała się do współczesnych realiów gospodarczych. Wyrazem jest zbudowanie zaufania i dobrych relacji między administracją skarbową a podatnikami.

Wprowadzone zmiany organizacyjne, w wyniku których służby wcześniej działające niezależnie od siebie, od 1 marca 2017 r. zaczęły funkcjonować jako jedna zintegrowana struktura - przyniosły oczekiwane korzyści. Wskazane w pierwszej 
części argumenty prowadzą do sformułowania słusznych wniosków, przemawiających za koniecznością reformy aparatu skarbowego. Analiza wyników dowodzi, że reforma administracji skarbowej była potrzebna i przyniosła zakładane efekty. Zintegrowana Krajowa Administracja Skarbowa w sposób efektywny i skuteczny realizuje zakreślone cele. Wskazówką do ich kontynuowania jest zarządzenie w sprawie kierunków działania i rozwoju Krajowej Administracji Skarbowej na lata 2017-2020.

Odnosząc się do zawartej na wstępie myśli przewodniej: „Administracja skarbowa przyjazna - efektywna - nowoczesna", przyjęto, że jednym z podstawowych celów administracji skarbowej jest dążenie do wprowadzenia mechanizmów administracji przyjaznej, co wiąże się ze wzmocnieniem funkcji usługowych i kontrolnych oraz zapewnieniem podatnikom ułatwień w dobrowolnym wypełnianiu obowiązków podatkowych. Realizacja tego celu odbywa się poprzez zagwarantowanie sprawnej komunikacji z klientami, kształtowanie relacji pomiędzy administracją i podatnikami w oparciu o klimat otwartości i przejrzyste standardy postępowania.

Administracja skarbowa przyjazna wpłynie na osiągnięcie drugiego celu - podniesienia efektywności administracji skarbowej. Tylko dobrowolne i terminowe uiszczanie należności publicznoprawnych jest najtańszą i najefektywniejszą formą poboru.

Administracja skarbowa powinna być administracją nowoczesną, co przejawia się między innymi we wprowadzeniu programu powszechnej informatyzacji, aby pozyskiwać wiedzę o istniejącym i możliwym ryzyku oraz określać sposoby zapobiegania i przeciwdziałania naruszaniu obowiązków podatkowych (celnych) w sposób efektywny i automatyczny [Uzasadnienie do projektu z 14 maja 2007 r.].

\section{Literatura}

Biuletyn Informacyjny, 2004, Administracja podatkowa oraz system podatkowy w Polsce, Ministerstwo Finansów.

Fiuk G., 2005, e-podatki elektroniczne ustugi nowoczesnego państwa, Departament ds. Informatyzacji Resortu, Ministerstwo Finansów, IV Forum Informatyki w Administracji, Ciechocinek.

Gajewski D., Nowak-Far A., 2016, Krajowa administracja skarbowa-propozycja konsolidacji aparatu skarbowego a uszczelnienie systemu podatkowego, Analizy i Studia, nr 2, CASP.

Izdebski J., 2007, Pojęcie i zakres reform administracji publicznej na przykładzie Krajowej Administracji Skarbowej, Roczniki Nauk Prawnych, tom XVII, nr 2.

Jełowicki M., 1987, Nauka administracji. Zagadnienia wybrane, PWN, Warszawa.

Kasperowicz-Stępień A., 2004, Ryzyko w działalności polskiej administracji podatkowej, [w:] Owsiak S. (red.), Nauki finansowe wobec współczesnych problemów gospodarki polskiej, Akademia Ekonomiczna, Kraków.

Kierunki działania izb i urzędów skarbowych na lata 1999-2002, Ministerstwo Finansów, Warszawa (niepubl.).

Klonowska A., 2011, Kierunki rozwoju polskiej administracji skarbowej w świetle realizacji zasad strategii relacji z podatnikami, Zeszyty Naukowe Uniwersytetu Ekonomicznego w Krakowie, nr 862.

Kosińska R., Ruśkowski E., Woltanowski P., 2016, Efektywność stużb podatkowych w okresie ich reformowania - wybrane zagadnienia, Finanse, Rynki Finansowe, Ubezpieczenia, nr 6 (84), cz. 2. 
Kosińska R., Ruśkowski E., Woltanowski P., 2014, Zarządzanie luka podatkowa w polskim systemie podatkowym przez organy podatkowe, [w:] Raczkowski K. (red.), Zarzadzanie w systemie gospodarczym. Szanse i zagrożenia, Wolters Kluwer, Warszawa.

Kulicki J., 2014a, Administracja danin publicznych w Polsce, Wydawnictwo Sejmowe, Warszawa.

Kulicki J., 2014b, Kierunek reformy administracji danin publicznych, Analizy, nr 10, Biuro Analiz Sejmowych.

Kulicki J., 2016, Koncepcja Krajowej Administracji Skarbowej w świetle problemów administracji danin publicznych, Analizy i Studia, nr 2, CASP.

Leoński Z., 2002, Refleksje nad problematyka reform administracji publicznej w Polsce, [w:] Łukasiewicz J. (red.), Nauka administracji wobec wyzwań wspótczesnego państwa prawa, Towarzystwo Naukowe Organizacji i Kierownictwa, Rzeszów-Cisna.

Uchwała nr 8 Rady Ministrów z dnia 14 lutego 2017 r. w sprawie przyjęcia Strategii na rzecz odpowiedzialnego Rozwoju do roku 2020 (z perspektywą do 2013 r.), Dziennik Urzędowy z 2017, poz. 260.

Uchwała nr 46 Rady Ministrów z dnia 25 kwietnia 2017 r. w sprawie Wieloletniego Planu Finansowego Państwa na lata 2017-2012, Dziennik Urzędowy z 2017, poz. 439.

Ustawa z dnia 28 września 1991 r. o kontroli skarbowej, Dz.U. z 2016 r., poz. 720 i 1165.

Ustawa z dnia 21 czerwca 1996 r. o urzędach i izbach skarbowych, Dz.U. z 2015 r., poz. 578 oraz Dz.U. z 2016 r., poz. 1810.

Ustawa z dnia 27 sierpnia 2009 r. o Służbie Celnej, Dz.U. z 2016 r., poz. 1799.

Ustawa z dnia 10 lipca 2015 r. o administracji podatkowej, Dz.U. z 2015 r., poz.1269, 1513 i 2184 oraz Dz.U. z 2016 r., poz. 394 i 905.

Ustawa z dnia 16 listopada 2016 r. o Krajowej Administracji Skarbowej, Dz.U. z 2019 r., poz. 768 ze zm. Uzasadnienie do projektu z dnia 14 maja 2007 r. ustawy o Krajowej Administracji Skarbowej.

Uzasadnienie do projektu z dnia 17 lutego 2016 r. ustawy o Krajowej Administracji Skarbowej - Projekt ustawy o Krajowej Administracji Skarbowej - druk sejmowy nr 826, VIII kadencja.

www.bankier.p1/ (3.03.2017).

www.inforfk.pl/ (18.11.2016).

www.mf.gov.pl/ (7.02-30.03.2018).

www.mf.gov.pl/de/ministerstwo-finanow/dla-mediow/wywiady/marian-banas/ (8.01.2018).

www.tvsierpc.pl/ (18.02.2018).

www.wgospodarce.pl/informacje/47237-kas-czyli-reforma (8.03.2018).

www.wpolityce.pl/ (18.02.2018).

www.wyborcza.pl/7,155287,23365498, nik (7.05.2018).

Zarządzenie Ministra Rozwoju i Finansów z dnia 25 lipca 2017 r. w sprawie kierunków działania i rozwoju Krajowej Administracji Skarbowej na lata 2017-2020, Dziennik Urzędowy Ministra Rozwoju i Finansów z 2 sierpnia 2017 r., poz. 144. 